\title{
ATXN1 Gene
}

National Cancer Institute

\section{Source}

National Cancer Institute. ATXN1 Gene. NCI Thesaurus. Code C129915.

This gene is involved in both RNA metabolism and chromatin binding. 